Journal Universitas Muhammadiyah Gresik Engineering, Social Science, and Health International Conference (UMGESHIC)

UMGCINMATIC : $1^{\text {st }}$ Rethinking Education during Covid-19 Era: Challange and Innovation

\title{
DEVELOPMENT OF "My Home" MODULE BASED ON GRESIK LOCAL WISDOM FOR ELEMENTARY SCHOOL
}

\author{
Author \\ Widi Yani ${ }^{1}$, Arya Setya Nugroho', Nanang Khoirul Umam ${ }^{3}$ \\ Student of Elementary School Teacher Education, Universitas Muhammadiyah \\ Gresik $^{\mathbf{1}}$, Lecturer of Elementary School Teacher Education, Universitas \\ Muhammadiyah Gresik ${ }^{2}$, Lecturer of Elementary School Teacher Education, \\ Universitas Muhammadiyah Gresik ${ }^{3}$
}

widi5087@gmail.com ${ }^{1}$, aryasetya@umg.ac.id ${ }^{2}$, nanang.khu@umg.ac.id ${ }^{3}$

\begin{abstract}
This research is motivated by teachers who still rarely use the companion module, especially on the material of geographical conditions. So this study aims to determine the validity and effectiveness of the learning module "My Home" for Class IV MI. Al-Mathlabatul Khoiriyah. The method in this study uses a 4-D model but the researcher only uses 3 stages, namely, define, design, develop. In the development stage, researchers validate, revise, and test 10 students. So that the data collection techniques used are validation of linguists, materials, graphics, culture, and the distribution of response questionnaires. The subjects in this study were 4 expert validators. The results of the development of this learning module meet the feasibility indicators of the expert validators. The results of the validation of linguists got a score of $82.5 \%$, material, and graphic experts got a score of $81.5 \%$, cultural experts got a score of $96 \%$, and includes very decent criteria. The novelty of this research lies in the illustration of the design of the learning modules used, and the subject matter related to the culture in Gresik. Based on the validation results, this learning module can be used in the learning process.
\end{abstract}

Keywords: 4-D model, learning module for geographical conditions

\section{INTRODUCTION}

Teaching materials are an important component in learning in schools. According to Pannen (1997:7) teaching materials are materials or subject matter systematically arranged that are used by teachers and students in the learning process. Teaching materials that are developed and compiled by the teacher are more effective and efficient because they are arranged according to the characteristics of students. It can be concluded that teaching materials are a set of materials that are arranged with an attractive appearance so that they can facilitate students.

There are various types of teaching materials, one of which is the module. The module is suitable to be applied to students according to the opinion (Dewi, 2017) that the module is 
a written teaching material with the aim that students can learn independently without or with teacher guidance. At MI Al-Mathlabatul Khoiriyah the modules used are only based on learning materials. This is evidenced by the results of interviews, researchers found the findings of a module book that only contains material on diversity in social studies learning. This module is considered lacking because it only contains material without including cultural education in it. By inserting cultural education, it can be an alternative for students to know the culture and traditions that exist in the surrounding environment.

The results of interviews were conducted by researchers with class IV MI teachers. AlMathlabatul Khoiriyah found several problems, namely the lack of students' understanding of the material, the learning process was only centered on teacher books and student books. The limitations of the learning modules used tended to make students feel bored and busy with other friends. Mrs. Eni Muslimah, SPdI as the homeroom teacher for class IV MI. AlMathlabatul Khoiriyah said that of the total number of students in class IV, there were 55\% of students who had difficulty solving problems related to the geographical conditions around them, one of the factors that influenced the above problems was the lack of companion modules for students. Modules are structured to make it easier for students to learn independently, because the nature of the module itself is self-instruction, namely the module can be studied alone as a substitute for the teacher. The use of appropriate learning modules will affect the level of understanding of students.

In addition to the problems above, the problem that exists in the current era is the waning of local wisdom values that develop in society as one of the impacts of globalization. The existence of globalization has resulted in many cultures entering, causing a decline in character values in each individual. The influence of globalization makes students lose their personality, this is shown from the results of interviews conducted by researchers with fourth-grade teachers at MI Al-Mathlabatul Khoiriyah. Judging from the behaviour of many students who are impolite, less sensitive to their social environment, and so on.

Currently, students tend to behave and behave like westerners. Eastern culture began to fade with the influence of western culture. The development of the learning module developed by the researcher is named "My Place of Living". This learning module will be developed in terms of geographical conditions KD 3.3 theme 8 sub-theme 1 learning 3, social studies content.

This research is limited to the development, which will be validated by 4 validators, namely linguists, materials experts, graphic experts, and cultural experts. Thus, the purpose of this study was to determine the validity and response of students to the development of the learning module "My Home" based on Gresik's local wisdom for class IV MI. Al-Mathlabatul Khoiriyah.

\section{METHODS}

This research was conducted at the University of Muhammadiyah Gresik and MI. AlMathlabatul Khoiriyah in the even semester of the 2021 academic year. While the subject of this research is a linguist validator, namely Afakhrul Mas'ub Bakhtiar, M.Pd. material expert 
validator namely Eni Muslimah, S.PdI graphic expert validator namely Darmawan Aditama, MT cultural expert validator namely Kris Adji Wahono, S.Pd. This type of research is development research. The research procedure used in this study uses a 4-D model. The 4-D model is carried out in four stages, namely defining, designing, developing, and disseminating (Kurniawan \& Dewi, 2017) but researchers only use 3 stages, namely defining ), design (design), development (develop). Stage of development (develop), the researcher conducted a trial with 10 students, validation, and revision. The definition stage consists of: (1) front end analysis (2) student analysis (3) task analysis (4) concept analysis (5) learning objectives analysis. The design phase consists of: (1) preparation of tests (2) selection of teaching materials (3) selection of formats (4) initial product design. The development stage consists of: (1) validation, and (2) revision. The following is the flow of research procedures for modifying a 4-D model into a 3-D model: (1) preparation of tests (2) selection of teaching materials (3) selection of formats (4) initial product design. The development stage consists of: (1) validation, and (2) revision. The following is the flow of research procedures for modifying a 4-D model into a 3-D model: (1) preparation of tests (2) selection of teaching materials (3) selection of formats (4) initial product design. The development stage consists of: (1) validation, and (2) revision. The following is the flow of research procedures for modifying a 4-D model into a 3-D model:

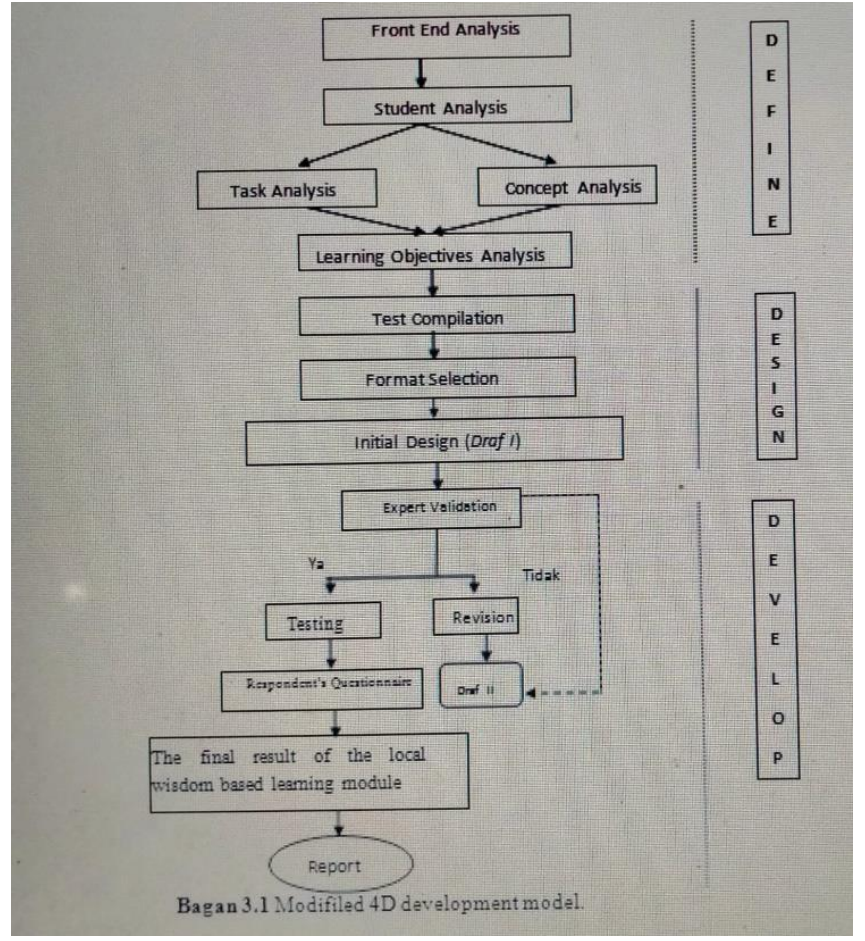

Figure 1. Modification of the 4-D Development Model to 3-D

The data collection technique used by researchers to obtain data is by validating language, material, graphics, and culture. Thus, the data collection instruments used were linguist validation sheets, materials, graphics, and cultural expert validation sheets.

The results of the validity of the validators are calculated using the formula: SMK $=5$ 
XV (Source: Sugiyono 2012) After the results of the validity are known the percentage, it can be matched with the following validity criteria:

\begin{tabular}{|c|c|}
\hline Preset & Criteria \\
\hline $81 \%-100 \%$ & Very good \\
\hline $61 \%-80 \%$ & Well \\
\hline $41 \%-60 \%$ & Pretty good \\
\hline $21 \%-40 \%$ & Not good \\
\hline $0 \%-20 \%$ & Very Not Good \\
\hline
\end{tabular}

Table 1. Percentage of Eligibility Interval

(Arikunto S, 2007)

The results of the validation of the learning module can be said to be feasible if it meets the feasibility indicator of $81 \%$ with very feasible criteria.

In this study, the analysis of student responses used the Guttman scale which provided two answer choices, for example, yes-no, never-never, and others. Therefore, the data generated is in the form of numbers where positive answers by students are given a number 1 and negative answers are given a number 0 .

\begin{tabular}{|l|l|}
\hline $\begin{array}{l}\text { Average } \\
\text { Score }\end{array}$ & Category \\
\hline $0-20$ & $\begin{array}{l}\text { Very } \\
\text { Inappropriate }\end{array}$ \\
\hline $21-40$ & Not feasible \\
\hline $41-60$ & less worthy \\
\hline $61-80$ & Worthy \\
\hline $81-100$ & Very Worthy \\
\hline
\end{tabular}

Table 2. Percentage of User Response Module Source: Riduwan (2013)

The above assessment can be used as a reference for research results to determine the feasibility of learning modules on geographical conditions. The module is said to be feasible if the score obtained is $>61 \%$ of user responses (users) in the good/positive category.

\section{RESULT AND DISCUSSION}

This section is the result of the research on the "My Place of Residence" learning module based on Gresik Local Wisdom which has been validated by validators of linguists, materials, graphics, and culture experts. The data is obtained by giving the instrument a validation sheet to the validator. The development model used in this study is the 4-D Thiagarajan model. However, the researcher only carried out three stages, namely defining the design stage and the development stage. For the development stage, the researchers 
validated, revised, and tested students using a response questionnaire.

The following are the results of the recapitulation of values from the validators of the "My Place" learning module

\begin{tabular}{|c|c|c|c|c|}
\hline \multirow[t]{2}{*}{ No. } & \multirow[t]{2}{*}{ Rated aspect } & Score & \multirow[t]{2}{*}{ SMK } & \multirow[t]{2}{*}{ RK } \\
\hline & & A & & \\
\hline \multicolumn{5}{|c|}{ Language Aspect } \\
\hline 1. & straightforward & 9 & 10 & 90 \\
\hline 2. & Communicative & 5 & 10 & 50 \\
\hline 3. & $\begin{array}{l}\text { Dialogic and } \\
\text { Interactive }\end{array}$ & 4 & 5 & 80 \\
\hline 4. & $\begin{array}{l}\text { Compatibility } \\
\text { with } \\
\text { Development } \\
\text { Learners }\end{array}$ & 8 & 10 & 80 \\
\hline 5. & $\begin{array}{l}\text { Conformity } \\
\text { with Language } \\
\text { Rules }\end{array}$ & 7 & 10 & 70 \\
\hline \multicolumn{2}{|c|}{ Total Score } & 46 & 60 & 456.5 \\
\hline \multicolumn{2}{|c|}{ Percentage } & \multicolumn{3}{|c|}{$82.5 \%$} \\
\hline \multicolumn{2}{|c|}{ Criteria } & \multicolumn{3}{|c|}{ Very Worthy } \\
\hline \multicolumn{5}{|c|}{ Material Aspect } \\
\hline 6. & $\begin{array}{l}\text { Material } \\
\text { suitability with } \\
\text { Basic } \\
\text { competencies }\end{array}$ & 13 & 15 & 86.6 \\
\hline 7. & $\begin{array}{l}\text { Material } \\
\text { Accuracy }\end{array}$ & 19 & 25 & 76 \\
\hline 8. & $\begin{array}{l}\text { Material } \\
\text { Update }\end{array}$ & 9 & 10 & 90 \\
\hline 9. & $\begin{array}{l}\text { Encourage } \\
\text { Curiosity }\end{array}$ & 8 & 10 & 80 \\
\hline \multicolumn{2}{|c|}{ Total Score } & 49 & 60 & 332.6 \\
\hline \multicolumn{2}{|c|}{ Percentage } & \multicolumn{3}{|c|}{$81.6 \%$} \\
\hline Crit & & \multicolumn{3}{|c|}{ Very Worthy } \\
\hline \multicolumn{5}{|c|}{ Graphic Aspect } \\
\hline 10. & Module Size & 9 & 10 & 90 \\
\hline 11. & $\begin{array}{l}\text { Module Cover } \\
\text { Design (Cover) }\end{array}$ & 34 & 40 & 85 \\
\hline 12. & $\begin{array}{l}\text { Module } \\
\text { Content Design }\end{array}$ & 79 & 100 & 79 \\
\hline \multicolumn{2}{|c|}{ Total Score } & 122 & 150 & 254 \\
\hline \multicolumn{2}{|c|}{ Percentage } & \multicolumn{3}{|c|}{\begin{tabular}{l|l|l} 
& $81.6 \%$ & \\
\end{tabular}} \\
\hline \multicolumn{2}{|c|}{ Criteria } & \multicolumn{3}{|c|}{ Very Worthy } \\
\hline \multicolumn{5}{|c|}{ Cultural Aspect } \\
\hline 13. & $\begin{array}{l}\text { The truth of the } \\
\text { substance of } \\
\text { local wisdom } \\
\text { Gresik }\end{array}$ & 5 & 5 & 100 \\
\hline 14. & The benefits of & 4 & 5 & 80 \\
\hline
\end{tabular}




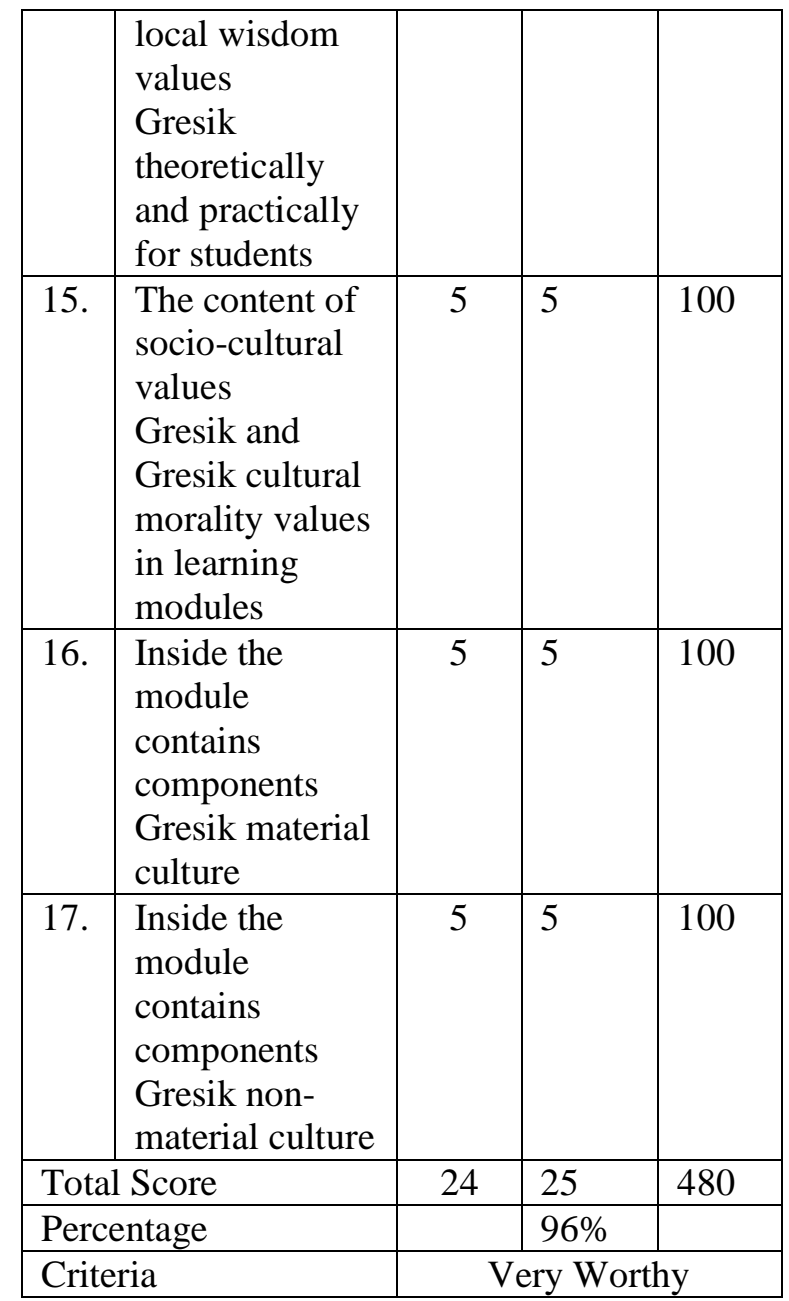

Table 3. Recapitulation of Module Validation Values

In table 3. shows that the results of the validation of the learning module on the language aspect get a score of $82.5 \%$, then material experts get a score of $81.6 \%$, graphic experts get a score of $81.6 \%$, cultural experts get a score of $96 \%$ which means the learning module "My Residence" has met the eligibility and can be used in the learning process.

Based on the validation results that have been obtained, the learning module developed by the researcher also received comments and suggestions for revision. Revisions are made as a form of improvement of the learning modules that have been developed so that the media becomes even better. The following are criticisms and suggestions given by expert validators.

\begin{tabular}{|l|l|l|}
\hline $\begin{array}{l}\text { Validator } \\
\mathbf{1}\end{array}$ & \multicolumn{1}{|c|}{$\begin{array}{c}\text { Comments \& } \\
\text { Suggestions }\end{array}$} & \multicolumn{1}{c|}{ Repair } \\
\hline 1. & $\begin{array}{l}\text { The use of images in } \\
\text { paragraphs must be } \\
\text { consistent, do not } \\
\text { use different frames. }\end{array}$ & $\begin{array}{l}\text { Using appropriate } \\
\text { frames }\end{array}$ \\
\hline 2. & $\begin{array}{l}\text { The use of } \\
\text { background color } \\
\text { adjusts to the image }\end{array}$ & $\begin{array}{l}\text { Adjust the } \\
\text { background color. }\end{array}$ \\
\hline
\end{tabular}




\begin{tabular}{|l|l|l|}
\hline & used & \\
\hline 3. & $\begin{array}{l}\text { Pay attention to the } \\
\text { use of punctuation }\end{array}$ & $\begin{array}{l}\text { Adjusting the use } \\
\text { of punctuation }\end{array}$ \\
\hline 4. & Good & $\begin{array}{l}\text { No need for } \\
\text { revision, because } \\
\text { according to } \\
\text { experts the material } \\
\text { is following KI and } \\
\text { KD }\end{array}$ \\
\hline 5. & $\begin{array}{l}\text { It's good, please } \\
\text { improve again }\end{array}$ & $\begin{array}{l}\text { No need for } \\
\text { revision because } \\
\text { according to the } \\
\text { validator it is } \\
\text { appropriate and } \\
\text { easy to understand }\end{array}$ \\
\hline
\end{tabular}

Table 4. Results of the Revision of the Validators

The definition stage consists of 5 steps including front-end analysis. According to Thiagarajan, et al (1974) front-end analysis aims to raise and determine the basic problems encountered in learning, so that a development of teaching materials is needed. With this analysis will get a picture of the facts, and alternative solutions to basic problems, which facilitate the determination and selection of teaching materials.

After that, the analysis of the students was carried out. According to (Dewa, 2010) student analysis is needed to determine the characteristics of students following the development of the learning module to be developed. Task analysis aims to identify the tasks given to students, concept analysis aims at relevant concepts that are used as references in developing learning modules.

After the definition stage is complete, then the design stage is carried out. This stage has 4 steps including a. test preparation. According to Thiagarajan, et al (1974) the preparation of the test is a step that connects the definition stage and the design stage at this stage the preparation of the benchmark reference test is based on the specification of learning objectives and student analysis. The developed test is adjusted to the level of students' cognitive abilities. b. selection of teaching materials. (Tri Astuti, 2020) said the selection of teaching materials was carried out to identify teaching materials that were relevant to the characteristics of students.

The selection of teaching materials following the conditions of students can assist students in achieving basic competencies. c. the selection of formats in the development of learning modules is intended to design or design learning content.The module format developed meets the attractive criteria and helps students in learning. d. initial product design. (Ermawati, 2020.) revealed that the initial product design in question is the design of all learning modules that must be done before the trial is carried out. In designing this learning module, the researcher used Corel Draw and PhotoShop software.

The validity of the "My Place of Living" learning module can be seen through the validation results from the validators of linguists, materials, graphics, and cultural experts. Data were obtained through language validation sheets, materials, graphics, and cultural validation 
sheets. Based on the results of the validation, an average percentage of $85.35 \%$ was obtained, which means that the learning module "My Home" can be used in the learning process with a few revisions. As for the criteria from the results of the material expert validator, it is very feasible, meaning that the content of the material contained in the learning module can be used or presented in the learning process.

The learning module developed by the researcher is adjusted to the learning needs, where the researcher adapts to the characteristics of the fourth-grade MI students. Al-Mathlabatul Khoiriyah

To find out the effectiveness of the "My Place" learning module in class IV MI. Al-Mathlabatul Khoiriyah Kebomas-Gresik conducted a questionnaire distribution after the learning process using the module, the questionnaire was given to students who had seen the learning module directly. During the COVID-19 pandemic, researchers only used 10 students to minimize crowds and always comply with health protocols.

\begin{tabular}{|l|c|c|c|l|}
\hline No. & Name & 'Yes" & "No" & Information \\
\hline 1. & A A & 9 & 0 & Positive \\
\hline 2. & FA & 9 & 0 & Positive \\
\hline 3. & FAP & 9 & 0 & Positive \\
\hline 4. & MS & 9 & 0 & Positive \\
\hline 5. & MDS & 9 & 0 & Positive \\
\hline 6. & MDA & 8 & 1 & Positive \\
\hline 7. & MKPS & 8 & 1 & Positive \\
\hline 8. & MH & 9 & 0 & Positive \\
\hline 9. & NKA & 9 & 0 & Positive \\
\hline 10. & RP & 9 & 0 & Positive \\
\hline \multicolumn{2}{|c|}{ Amount } & $\mathbf{8 8}$ & $\mathbf{2}$ & Positive \\
\hline
\end{tabular}

Table 5. Results of Obtaining Student Response Questionnaires

By the calculation results show that the results of the questionnaire response percentage of students get the results of $97.7 \%$, which means that it falls into the specified criteria $>60 \%$ where the learning module can be said to be positive because it has met the predetermined criteria.

In developing the learning module, the researcher also pays attention to the language aspect, including the accuracy of the sentence structure following the aspects of the linguistic component, namely, the accuracy of the sentence structure and the standard grammar of the term. The arrangement of the language used by the researcher is not the everyday language or the local language. The use of language is also adapted to the development of students so that it is communicative and easy to understand.

The content feasibility component in the learning module that has been developed meets the aspects of content feasibility, including (a) The scope of the material is assessed from the completeness of the material and the breadth according to KI3 and its KD, (b) The accuracy of the material is assessed from the accuracy of facts, concept rules, (c) Dimensions of skills assessed from the accuracy of the material and the accuracy of the activities. 
The graphic component in this learning module is following the items contained in this component, namely, the suitability of the illustration, the description of the image placed close to the image, the type of font used is not too much and the use of letter variations is not excessive, and the placement of decorations/illustrations on the page does not interfere. clarity and delivery of information in the text.

The cultural component in this learning module is following the items contained in this component, namely, the truth of the Gresik cultural substance.

In general, the learning modules developed by researchers have several advantages, including (1) overcoming the limitations of time, space, and the senses of both students and teachers. (2) allows students to measure and evaluate their own learning outcomes. (3) the teacher can act as a mentor, not merely as a teacher. In addition to the advantages, the learning module developed by the researcher also has several drawbacks, including: (1) not all students can learn independently, but need the help of the teacher. (2) not all materials can be modularized and not all teachers know how to implement learning using modules. (3) development costs in making learning modules take a long time.

\section{CONCLUSIONS AND SUGGESTIONS}

a. Conclusions

Based on the results of research conducted related to the development of learning modules based on Gresik local wisdom, it is still rare, this makes this research very important, especially for social studies material. The novelty of this research lies in the illustration of the design of the learning modules used, and the subject matter related to the culture in Gresik. It can be concluded that the development of teaching materials in the form of learning modules based on Gresik's local wisdom is needed so that students know the culture around them, especially the culture in the city of Gresik. the development of the learning module "My Home" developed by the researcher can be used in the learning process, because it has sufficient validity indicators, namely $81 \%$. This is indicated by the average percentage of validation data from media expert validators and material experts. The average validation result is $85.35 \%$ with very feasible criteria.

b. Suggestions

Based on the results of the conclusions and discussions, the researchers provide suggestions, including: (1) For teachers, using the "My Place" learning module which is categorized as very feasible can be an alternative to using learning modules during the learning process, especially on geographical conditions and making participants students are more enthusiastic and make it easier to understand learning material, the selection of varied learning media based on local wisdom can be an alternative in the learning process, besides that it can provide new experiences for students. (2) For researchers, researchers can examine other regional-based learning modules so that they can become alternative learning. 


\section{REFERENCES}

Akbar, S. (2015). Instrumen Perangkat Pembelajaran. Bandung: PTRemaja Rosdakarya. Daryanto. (2013) . Menyusun Modul:Bahan Ajar untuk Persiapan Gurudalam Mengajar. Yogyakarta: Gava Media.

Sugiyono. (2012). Metode Penelitian Kuantitatf, Kualitatif, dan R \& D.Bandung: Alfabeta.

Thiagarajan, S.S. (1974). Instructional Devolopment for Training Teacherts of Exceptional Childreen. Leadership Training Institute/SpecialEducation, Minnesota: University of Minnesota, Minneapolis.

Trianto. (2015). Model Pembelajaran Terpadu: Konsep, Strategi, dan Implementasinya dalam Kurikulum Tingkat Satuan Pendidikan (KTSP). Jakarta: Bumi Aksara.

Widodo,C.S. (2008).Panduan Menyusun Bahan Ajar BerbasisKompetensi. Jakarta: Elex Media Komputindo.

Prastowo, A. (2013). Panduan Kreatif Membuat Bahan Ajar Inovatif. Yogyakarta: DIVA Press.

Rafika, Nurrahmi (2017). Pengembangan Modul Berbasis Kearifan Daerah Istimewa Yogyakarta dengan tema Pendidikan. Yogyakarta:Universitas Negeri Yogyakarta.

Widiyoko, 2012. Tekhnik penyusunan instrumen penilaian. Yogyakarta:Pustaka Pelajar.

Dikmenjur. (2004). Kerangka Penulisan Modul. Jakarta: Dikmenjur,Depdiknas.

Dani, Sucianingsih. (2013) Analisis Bahan Ajar Seni Kerawitan Kelas IV. Jakarta: Universitas Pendidikan Indonesia.

Sukmadinata, N.S. (2007). Metode Penelitian Pendidikan. Bandung: PT. Remaja Rosdakarya. 